\author{
Vilma Bijeikienè \\ Vytautas Magnus University, Lithuania \\ Nemira Mačianskienè \\ Vytautas Magnus University, Lithuania
}

\title{
LITHUANIAN POLITICAL DISCOURSE: EXPRESSION OF AGENCY AND RESPONSIBILITY
}

\begin{abstract}
Summary. In light of the changing picture of gender representation in politics and most importantly in political leadership, Lithuania should be granted a special position among examples of women political leaders' success stories. On the one hand, the general proportion of female MPs in the Lithuanian Parliament Seimas ${ }^{9}$, is not at all impressive with 26 female (18\%) vs. 115 male (82\%) MPs in 2008-2012 term and 34 female (24\%) vs. 107 male (76\%) MPs elected in 2012. On the other hand, however, the highest political offices in Lithuania were held by women in 2008-2012 term: namely the President of Lithuania Dalia Grybauskaite,, the Speaker of Seimas Irena Degutiene, the Minister of Finance Ingrida Šimonyte and the Minister of National Defence Rasa Juknevičienè. The situation itself can be seen as a breaking point with regard to widely-quoted stereotypic assumptions, for instance, professions related to politics, economics and military issues are typical male professions (R. Lakoff, 2000, 2003; Walsh, 2001) or some underlying statistical evidence like the one provided by Wodak (2003) that women rarely occupy the top authoritative positions. Moreover, with around two years in office in her second term President Grybauskaite has been largely enjoying people's support in popularity polls. This not only demonstrates a dramatic shift from traditional gender divisions of women being 'silenced' (Cameron, 1998, R. Lakoff, 1975), but also a rather significant move from the female discourse of resistance and survival presented by Martin-Rojo (1997) to the discourse of success. G. Lakoff (2004) claims that for political discourse to be successful it needs to be built on values. With these observations in mind, the present paper aims to investigate how such values as responsibility, fairness, active agency, etc. are delivered through choices of pronouns (Cf. Wilson, 1990) and equivalent morphological forms by the main political leaders in Lithuania: the President Dalia Grybauskaite and the former Prime Minister Andrius Kubilius. The data for analysis come from transcripts of political interviews available in the media. The study is based mainly on qualitative discourse analysis with some quantification for comparison.
\end{abstract}

Keywords: agency, gender, leadership, political discourse, pronominal forms, selfreference.

${ }^{9}$ The statistics is supplied by The Central Electoral Commission of the Republic of Lithuania. Retrieved from: http://www.vrk.It/lt/2012_seimo_rinkimai/statistika.html. 


\section{Theoretical background}

\section{Issues of female leadership and discourse}

Starting with Robin Lakoff's seminal work Language and Woman's Place of 1975 (cf. 2004), much research has been carried out on whether gender influences linguistic practices and how this influence may surface out. What R. Lakoff did was to introduce quite a daring and disputable hypothesis that women are "systematically denied access to power, on the grounds that they are not capable of holding it as demonstrated by their linguistic behavior" (Lakoff R., 1975, p. 7). This snow ball rolled to avalanche studies within gender and language in regard to various social context extending from everyday encounters, as for instance, in the work of Tannen (1990) or Cameron (1998b), to workplace discourse like in Tannen (1994), Thimm, Koch \& Schey (2003), Martin-Rojo (1997), Martin-Rojo and Gomez Esteban (2005) or Holmes (2005) and to political sphere as in the research of Lakoff Tolmach (2000), R. Lakoff (2003) and Wodak (2003, 2005).

Cameron revealed and criticized the exclusion of women, or women's discourse, from the discourses that have power and influence in society claiming that women were long silent or silenced in "society's most valued linguistic registers" including political discourse (1998a, p. 3). Martin Rojo (1997) points to an important change in women's discourse signifying their struggle for power and acceptance in society. In Martin-Rojo's terms, at the end of the 20th century to break through male dominance in public contexts women assumed a discourse of resistance. In numerous other studies it was revealed that professions and discourses of power such as politics, economics, military, etc. are still seen as typically male (cf. Walsh, 2001). With regard to the last decade tendencies, Wodak $(2003,2005)$ discovered that in the EU parliament there has been an increase in female members ${ }^{10}$; however, this increase does not mean a proportional increase in female politicians in the top leadership positions. Presidencies of European institutions, for instance, the EU Parliament (President

10 Gender composition of the current EU Parliament: 37\% women MEPs and $63 \%$ male MEPs. Retrieved from: http://www.europarl.europa.eu/elections2014-results/en/genderbalance.html. 
Martin Schulz), European Council (President Donald Tusk), European Commission (President Jean-Claude Juncker), etc., are largely assumed by men.

\section{Gender in Lithuanian politics: President Dalia Grybauskaitė and Ex-Prime minister Andrius Kubilius}

In view of the reasoning above, the political arena in Lithuania during the parliamentary term of 2008-2012 could be regarded as presenting quite an advanced picture with the major political posts held by female politicians: Irena Degutienè as Speaker of the Parliament, Rasa Juknevičienè as Minister of National Defence, Ingrida Šimonytè as Minister of Finance and most importantly the President of Lithuania Dalia Grybauskaitè, who was re-elected for her second term of presidency in 2014. Consequently, their discourse could be no longer seen as the discourse of exclusion and resistance but should be regarded as the discourse of success and would be of interest to investigate as to what features it demonstrates and how it differs from the discourse of male political leaders. Moreover, the success of the female politicians is also demonstrated by their positive approval ratings, especially with regard to the performance of President Grybauskaitè during her first term in office (see Figure 1).
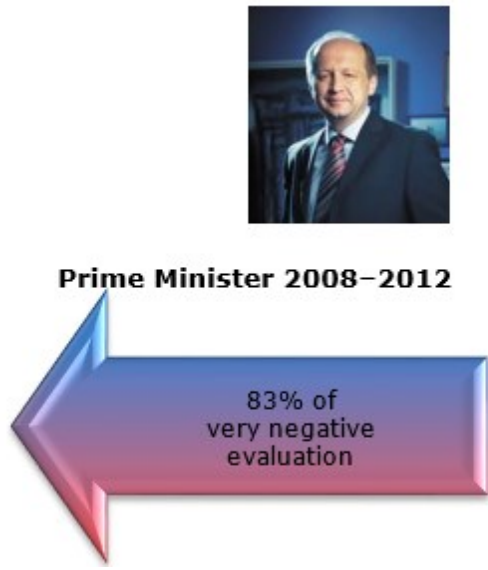

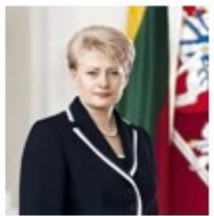

President 2009-2014

(re-elected in 2014)

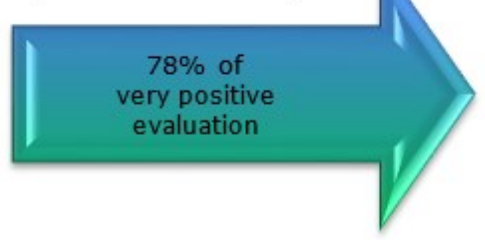

Fig. 1. Approval ratings of Kubilius and Grybauskaitè in $2012^{11}$

\footnotetext{
11 The ratings are provided by "Baltijos tyrimai", a company of public opinion surveys, retrieved from: http://www.delfi.It/news/daily/lithuania/visuomenes-lyderiu-populiarumorikiuote-pradeda-dgrybauskaite-uzbaigia-akubilius. $d$ ? id $=58782173$.
} 
In contrast, the Prime Minister Andrius Kubilius used to receive very negative evaluation in public opinion polls (see Figure 1 ) which could be regarded to have been gradually dropping over his term. His negative approval ratings could be explained by the fact that he, as the leader of the Cabinet, was considered responsible for the painful reforms he had to assume to cope with the economic crises in Lithuania in 2009-2011. The President's approval ratings, on the other hand, were always high during her first term of presidency. It is important to note that in Lithuania the main responsibility of the President is foreign policy; nevertheless, President Grybauskaite is highly involved in domestic issues and reforms. Moreover, she is part of the executive power in the same way as the Government with the Prime Minister in the fore. Under these circumstances, her approval ratings could have followed the sad destiny of those of the Prime Minister in 2012. However, the negative effects of the reforms on Lithuanian people did not harm President Grybauskaitè as they harmed the approval ratings of the former Prime Minister. As a result, without going into detail investigation where linguistics and politics diverge, it can be suggested that the President, among other things leading to her political success, employs a more successful discursive style, namely the discourse that is more appealing to the public, while the former Prime Minister was strongly failing to meet the expectations of the people, among other things, by not employing the right discursive practices.

\section{Conceptualisation of successful political discourse}

The question of how to use language to gain political success can never be unambiguously answered. There can be various research-based findings as well as speculations and hunches as to what assures political success and as to what language leads to political success. A plausible link between political success and political discourse has been drawn by G. Lakoff (2004). As a cognitive linguist and a researcher into political discourse (cf. G. Lakoff, 1992, 1996, 2003), G. Lakoff has been also active in discussing the practical steps leading towards electoral success. In his terms, talking programmes and manifestoes, what politicians often occupy themselves with, bore the general public and guarantee nothing but 
electoral failure. Along the same lines, in Lithuanian political context ${ }^{12}$, the majority of voters do not read pre-election manifestoes rather looking for other, more appealing, criteria to make their electoral choices. According to G. Lakoff, in order to win politicians need to build their speeches on values such as:

Empathy, responsibility, protection, strength, fairness, fulfilment in life, freedom, opportunity, prosperity community, service, cooperation, trust, honesty and open communication.

G. Lakoff ascribes these values to progressive or liberal political affiliation. Nevertheless, they can be truly regarded as universal human values that could be appealing to the general public of various political persuasions.

\section{Hypothesis and Methodology}

The present study aims to investigate how the universal values such as responsibility, fairness, honesty, active agency, etc. are delivered through the choices of self-reference forms, namely pronouns and equivalent morphological forms, by the main political leaders in Lithuania and how this usage relates to gender and political success. Two Lithuanian political leaders have been chosen for the study: Lithuanian President Dalia Grybauskaitè and former Prime Minister Andrius Kubilius. Given that President Grybauskaitè enjoys a stronger support by the public, it is hypothesised that her discourse, more particularly the use of selfreference forms, is more reflective of universal values than the discourse of the former Prime Minister Kubilius.

Methodologically, it is a small scale discourse analytical study based on a combination of quantitative and qualitative methodologies. The data are taken from political interviews with President Grybauskaitè ${ }^{13}$ and former Prime Minister

\footnotetext{
12 Opinion expressed by a political scientist Vincentas Vobolevičius in a mass media article. Retrieved from: http://iq.It/lietuva/partiju-programos-tarp-pazadu-ir-propagandos.

13 Retrieved from: http://www.president.It/It/prezidento_veikla/prezidente_ziniasklaidoje/prezidente_ziniasklai doje_385/prezidentes_dalios_grybauskaites_interviu_zurnalui_iq_ne_zingsnio_atgal.html http://www.delfi.It/news/daily/lithuania/dgrybauskaite-lietuva-tikrai-pajus-antrasunkmecio-banga. $d$ ?id=59100013
} 
Kubilius $^{14}$ on current political issues in Lithuania, which appeared in the Lithuanian media and are available on line. The aim was to maintain a proportionate representation of the discourse of both politicians. Thus, the sample of Grybauskaitè's discourse consists of 2531 words, while the sample of Kubilius discourse contains 2542 words.

\section{Results}

As demonstrated in Figure 2, the types of self-reference forms used in the present study can be placed on a continuum of gradual distancing of the speaker from active agency or, in other words, as showing the speaker's decreasing personal responsibility. It thus starts with the first person singular form I as an individual self-reference form and the reflection of most willingness to assume personal responsibility. It is further followed by the first person plural form we as a collective self-reference form. The latter is then split into a number of Speaker inclusive we forms and a Speaker exclusive we form.

\begin{tabular}{|c|c|c|c|c|c|}
\hline \multirow{12}{*}{ 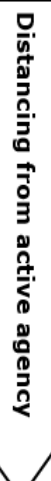 } & Types of self-reference & \multicolumn{2}{|c|}{ Grybauskaitè } & \multicolumn{2}{|c|}{ Kubilius } \\
\hline & $I$ & \multicolumn{2}{|l|}{51} & \multicolumn{2}{|c|}{43} \\
\hline & $W e=\mathrm{I}+$ the hearer & 1 & & \multicolumn{2}{|c|}{8} \\
\hline & $\begin{array}{l}\text { We=I+ my team (e.g. government, } \\
\text { party, advisors, etc.) }\end{array}$ & 5 & & \multicolumn{2}{|c|}{71} \\
\hline & $W e=\mathrm{I}+$ other government institutions & 22 & & \multicolumn{2}{|c|}{9} \\
\hline & $W e=$ I + Lithuanians / Lithuania & 27 & & \multicolumn{2}{|c|}{49} \\
\hline & $W e=\mathrm{I}+$ the Baltic states & $\mathbf{0}$ & \multirow{2}{*}{68} & 6 & \multirow{2}{*}{150} \\
\hline & $\begin{array}{l}\text { We }=\mathrm{I}+\text { other European countries/ EU } \\
\text { institutions }\end{array}$ & 4 & & 2 & \\
\hline & Speaker exclusive $W e$ & 9 & & \multicolumn{2}{|l|}{5} \\
\hline & Passive structures for self-reference & 3 & & \multicolumn{2}{|l|}{4} \\
\hline & Second person for self -reference & 2 & & \multicolumn{2}{|l|}{2} \\
\hline & Third person for self-reference & 3 & & \multicolumn{2}{|l|}{2} \\
\hline
\end{tabular}

Fig. 2. Types of self-reference analysed in the study and frequencies of their usage

\footnotetext{
${ }^{14}$ Retrieved from: http://www.ve.It/naujienos/lietuva/lietuvos-naujienos/andriaus-kubiliausinterviu-svedu-dienrasciui-kitos-iseities-nebuvo-685863; http://www.Irv.It/naujienos/?nid=5711; $\quad$ http://www.veidas.It/sesi-klausimai-andriuikubiliui; http://www.veidas.It/trumpasis-interviu-su-andriumi-kubiliumi.
} 
The self-reference forms most distancing from the deictic centre include: Passive structures for self-reference, Second person for self-reference and Third person for self-reference. The sample also includes the first person possessive pronouns e.g. my and our. Finally, it entails cases when the pronominal information is carried by the corresponding verb inflections without using the pronominal form, e.g. I go in Lithuanian is expressed through the verb form einu, while we go is expressed through the verb form einame.

The results reveal that Grybauskaitè uses Individual self-reference I more often than her counterpart, however, the margin is not very big. Both politicians use the Collective self-reference in the form of we more often than Individual selfreference in the form $I$. This can be regarded as a very much expected tendency given that the main principle of democratic politics is to represent others. In his analysis of political equivocation, Bull $(1998,2000)$ presents three faces that a political figure has to attend to, namely, one's "own individual face", "the face of significant others" and "the face of the party" (Bull, 2000, p. 225). For such significant political figures as the President and the Prime Minister, the importance of the three faces is highly increased. Moreover, both such political leaders have a broader scope of representation including their electorate, their country, the various interest groups, etc. Nevertheless, the numbers show that we forms are used more than twice as often by the Prime Minister than by the President. It is especially significant in the category of $I+m y$ team, in this case the government, the party and possibly his advisors, and in the category of $I+$ Lithuanians. The President, on the other hand, more often makes reference to herself and other government institutions, like the Parliament or the Government. In general, these results go along the lines of the hypothesis, namely Grybauskaite seems to assume her personal responsibility and active agency more than the Prime Minister, while the Prime Minister draws to collective responsibility more often. 


\section{Discussion}

\section{The main tendencies of using Individual self-reference in Grybauskaite's discourse}

A small quantitative difference in the use of Individual self-reference is made more significant when a qualitative discourse analytic approach is applied. With regard to universal values, which make an important focus of the present study, four patterns of Individual self-reference stand out in Grybauskaitè's discourse. First of all, it is the pattern of Communication of honesty \& openness. Consider the following example:

(1) $<\ldots>$ nes esu savikritiška $<\ldots>(<\ldots>$ because I am self-critical $<\ldots>)$;

(2) Labai noriu padaryti daug ir greitai $<\ldots>(<\ldots>$ I indeed want to do much and quickly $<\ldots>$ );

(3) Jei būčiau maniusi, kad kažką darau blogai, to tikrai nedaryčiau. (If I had thought I had been doing something wrong, I wouldn't be doing it.);

(4) Visada stengiuosi daryti tai, ką manau, kad tikslinga daryti pagal turima informacija $<\ldots>$ (I always try to do what I believe is plausible to be done in accordance with the existing information $<\ldots>$ );

(5) Iš tiesu nenorèčiau žaisti to žaidimo, kad atmetinéčiau istatymus tik dèl kai kuriu detaliu arba nežymios itakos (I truly wouldn't like to play that game of rejecting bills just because of some details or some influence.).

The italicised words in Lithuanian examples are the Individual self-reference phrases. All of them structurally highlight the speaker's willingness to assume personal responsibility. Moreover, emphasis is placed on the speaker's openness in communicating her possible mistakes and readiness to work. In (5) the straightforward acceptance of personal responsibility is strengthened through the 
use of metaphor POLITICS IS A GAME, whereby the speaker not only declares her staunch stance but also expresses her strong disapproval of politicians who make use of their status for their own interest, i.e. play political games and in that way abuse their political position to manipulate the public.

The second pattern is Communication of her firm resolution in juxtaposition with the wrongdoings of various institutions. For instance:

(6) Netgi sakyčiau, kad mano istatymo pataisos sulaukia atviro sabotažo kai kuriose savivaldybèse (I would even say that my amendments to bills are challenged by an open sabotage of local governments.);

(7) Pritariu, kad didele dalimi matau būtent šilumininku keršta ir sabotažą. (I agree that in the biggest part I see namely the revenge and sabotage of heating suppliers.).

In his discussion of successful strategies to win elections, G. Lakoff (2004) accentuates the importance of 'making the difference'; in other words, for a political force, be it a political party or a candidate running for presidency, it is of utter significance, firstly, to highlight that your political stance differs from that of the opponents and, secondly, to show how these differences manifest in your political discourse and performance. Considering examples (6) and (7) in view of G. Lakoff's reasoning, what Grybauskaite successfully does is to underscore her active performance through the use of Individual self-reference, as for instance, my amendments, in sharp contrast to the activity of her political rivals. To make this contrast sharper, the speaker employs negatively connoted phrasing such open sabotage in (6) or revenge and sabotage in (7) to indicate the actions of her opponents. Moreover, the reference form she uses to refer to the institution in (7), namely heating suppliers, strengthens the negative connotations attached to her political opponents given that Lithuanian people are particularly frustrated with high heating prices. Therefore, in this case, the President's reference to an institution through naming its failing function simultaneously highlights the President being in opposition to the activities that are disapproved by the public. 
Third among the patterns of Grybauskaitè's Individual self-reference is the pattern of Communication of strength, protection and fairness evidenced through the following instances:

(8) Tiesiog matau sąžinès ir politinès valios trūkumą. (I just see the lack of honesty and political will.);

(9) Tikrai reikalauju, kad būtu atlikta korupcinè analizè (I do insist that corruption analysis be carried out.);

(10) $<\ldots>$ kad tai valstybei brangiau kainuos, negu bus nauda, tuomet vetuoju ( $<\ldots>$ when it is going to cost the country more than the benefit received, I veto).

Strength, protection and fairness are the universal values which must be among the most appealing ones to the electorate and which are made good use of by the speaker in her discourse above. Grybauskaitè does not directly communicate how honest, strong-willed or fair she is as a politician, which could be frowned on by the public as boasting, but achieves this effect indirectly by strongly criticising those politicians who demonstrate, in her words, lack of honesty and political will (8). In juxtaposition to those politicians she not only manages to underscore her intact political reputation but also shows her strength in assuming the protection of people from acts of corruption (9) or budget waste (10).

Finally, the fourth pattern in the repertoire of Grybauskaite's Individual self-reference demonstrates her Focus on cooperation and collaboration, as for instance:

(11) Mèginu būti konstruktyvi ir parodyti Seimui, kad noriu bendradarbiauti ( $\mathrm{I}$ try to be constructive and show the Parliament that I want to cooperate.).

In the literature on language and gender, being collaborative and cooperative is traditionally regarded as a typical feature of feminine discourse (cf. Holmes \& Stubbe, 2003); however, in terms of G. Lakoff it is also a value admired by the 
electorate. Whether Grybauskaitè uses it effectively can yet be questioned. Her choice of the verb try ("mèginu" in Lithuanian) adds limitation to the performative force of her utterance and creates the effect of incompletion of the undertaken action, namely her attempt to be constructive in her communication with the Parliament.

\section{The main tendencies of using Individual self-reference in Kubilius' discourse}

In the discourse of former Prime Minister Andrius Kubilius there are three patterns of Individual self-reference. The first of them, which we called Communication of his past actions, could be interpreted as showing a significant divergence from the patterns in Grybauskaitè's discourse. Consider these examples:

(12) $<\ldots>$ praejusi karta dirbau ministro pirmininko poste $2000 \mathrm{~m}$. Rusijos krizès metu $(<\ldots>$ the last time I was Prime Minister was during the Russian crises in the year 2000);

(13) $<\ldots>$ netgi pats važinèdavau po renovuojamus daugiabučius $(<\ldots>$ I even used to go myself to the blocks of flats being renovated.);

(14) $\mathrm{Na}$, žinote, aš jau dvidešimt metu politikoje (Well, you know, I am already twenty years in politics.).

While Grybauskaite uses Individual self-reference to communicate her present or future actions such as I agree, I see, I veto, etc., Individual self-reference of Kubilius, ascribed to this pattern, is largely oriented towards the communication of what he did in the past. It is thin ice to walk on as the past deeds can be easily checked and such strategy can only work well with reference to tangible and wellknown past results. On the contrary, what the former Prime Minister (then the Prime Minister) did was to make abstract flashbacks to his career as the head of the Government, which then leaves an open space for the public to create their own cognitive images (G. Lakoff, 1987) as to what political results are made 
reference to. Given that the time mentioned in examples (12) and (14) brought various disappointments to different social groups, this use of self-reference can be interpreted by the public not as revealing his sense of responsibility and active agency, but rather as straightforward and unwarranted boasting. Along the same lines, example (13), which refers to a more tangible action of inspecting the renovation of housing, could, on the one hand, be seen as the focus on the value of service to the people, however, on the other hand, given that the process of renovation was one of the mostly criticised failures of Kubilius' Cabinet, the example does not score points for his active agency either. In the light of G. Lakoff's (2004) observation, namely that programmes bore people, while values win their support, this pattern of Kubilius could be seen as the reiteration of programmes which might not only bore people, but cause their disapproval as not implemented.

Another pattern that could be singled out among the cases of Individual self-reference in Kubilius speech is the pattern of Communication of disagreement illustrated by the following examples:

(15) Negaliu sutikti (I can't agree.);

(16) Aš nesakyčiau, kad labai daug, bet reikia pripažinti, kad taip buvo (I wouldn't say very much; but it is necessary to agree it was the case.);

(17) Man taip neatrodo (I don't think so.).

The pattern of disagreement is a part of various performative functions carried out through the use of Individual self-reference like I agree, I suppose, I believe, etc. Indeed both Grybauskaitè and Kubilius use them, however, the difference is that in Kubilius' discourse one finds negative forms which are not found in Grybauskaitè's usage.

We called the last pattern of Kubilius Individual self-reference forms Equivocation and ambiguity and ascribed to it the following cases of usage:

(18) Interviewer: $\mathrm{Ar}$ jis teisus, kad nè vienas pastatas nebuvo renovuotas? (Is he right saying that not a single building has been renovated?) 
Vilma BIJEIKIENĖ, Nemira MAČIANSKIENĖ

Kubilius: Na, neturiu laiko aiškinti šiu duomenu (Well, I have no time to explain this data.);

(19) Aš pasitikiu savo žmonèmis (I trust my people.).

The understanding of equivocation that is accepted in the present study is based on Bavelas, Black, Chovil \& Mullett's theory where it is conceptualised as "saying nothing while saying something" (Bavelas et al., 1990, p. 57, cf. Bull 2000). In other words, equivocation is seen as an interlocutor's attempt to avoid giving a straightforward answer to a question by simultaneously avoiding not to reply at all. The result then is a vague, ambiguous and equivocal response. Being such, equivocal discourse is an inevitable satellite of political interaction. Example (18) illustrates a typical case of equivocation when the reluctance to deliver an answer is based on the shortage of time (Bavelas et al., 1990). Example (19) is more subtle with respect to its interpretation as equivocal and ambiguous in comparison to (18). Yet the usage of the phrase my people can be seen as a case of ambiguity depending on what is included into the scope of reference of the possessive pronoun my. If the scope of reference extends up to all people of Lithuania then this usage could be interpreted as demonstrating the value of protection. Nevertheless, as the head of the government and the leader of a political party, Kubilius could have made reference to the government ministers, party colleagues, people loyal to his party, the electorate of his party, and many more options.

\section{The main tendencies of using Collective self-reference we in Grybauskaitë's discourse}

When it comes to Collective self-reference we, its usage in political discourse is generally much more frequent than Individual self-reference I, due to its linguistic and extra-linguistic properties. Namely, it has a broader scope of reference in terms of who else is added to the deictic centre I. Moreover, it corresponds better to the collective nature of political activities, especially in democratic systems. In Grybauskaitė's discourse the reference of we most often entails I+ other government institutions and $I+$ Lithuanians/Lithuania. With regard to the 
functions, her use of Collective self-reference we could be seen as showing focus on cooperation and collaboration which in this case is cooperation with the Parliament and the Government. For example:

(20) Mes visada kalbamés ir turime dialoga su Seimu <...> (We always talk and have a dialogue with the Seimas $<\ldots>$ ).

While underscoring cooperation, one can also see her use of collective selfreference forms to focus on positive achievements which could be viewed as a collective endeavour of a number of political institutions in a democracy as illustrated below:

(21) Labai svarbu, kad jau sukūrème elektros biržą ir rinką (It is very important that we have already created the electricity exchange market.);

(22) $<\ldots>$ viduje apsitvarkème per tuos 2-3 metus daug geriau, negu tai buvo padaryta 2007-2008 metais (<..> we have dealt with domestic issues much better over these 2-3 years than it was done in 2007-2008.).

In case of both, criticism and appraisal of the work of government institutions, she has to include herself into the scope of reference of we given that it is part of her responsibility due to the post she holds. Example (22) is especially interesting to consider. In this case she not only places emphasis on the positive work done by herself and other institutions, but also criticises the previous government and president. She juxtaposes the current positive results with the inadequate work of the previous president and government by indicating the years, which are the years before her term and the term of the present government.

Similarly, criticism and warning against wrongdoings could be seen as permeating through her use of the speaker exclusive we, as in the following examples:

(23) <...> mes žinome savo rèmus, mes negalime viršyti 3 proc. deficito ir negalime praktiškai beatodairiškai kaip darème iki šiol arba tiksliau, kaip turèjome daryti iki šiol, didinti valstybès skolos $(<\ldots>$ we know our limits, we 
can't exceed 3 per cent deficit and can't exceed the state debt so drastically as we have done or in fact had to do so far.);

(24) Problema net ne ta, kuo kūrename, o ta, kad šilumos ūkis taip pat yra monopolizuotas (The problem is not what fuel we use for heating, the problem is that the heating industry is monopolised.).

The speaker uses Collective self-reference we interchangeably including and excluding herself into the scope of references. For instance, although she criticises in (23) the government which is directly responsible for the implementation of laws, the President is part of executive power as well and the monetary policy is part of her responsibility which she here indirectly assumes through the use of we. Nevertheless, she further talks about the former government institutions by using Speaker exclusive we and in that way highlighting that the situation with the previous government was much worse. Similarly to the cases of Individual self-reference, her use of Speaker exclusive we, is meant to deliver her harshest criticism and thus to underscore her strength. In example (24) she does not include herself into the scope of we, as she is not involved in the heating processes herself, but she wants to show the public that she is very much involved into fighting the monopolies and protecting the public from high heating prices.

\section{The main tendencies of using Collective self-reference we in Kubilius' discourse}

In Kubilius' discourse Collective self-reference we is much more frequent showing his higher preference of collective responsibility than in the case of President Grybauskaitè. This tendency is especially supported by the fact that almost half of all instances can be categorised as $I+m y$ team (which can be the Government, the party or his advisors) emphasising the former Prime Minister's and, in many cases, the Government's shared responsibility, as demonstrated by the following examples: 
(25) Mes tikrai valdome krizę ir tai darome labai efektyviai (We are truly managing the crisis and we are doing it very effectively.);

(26) <...> mums labai gerai sekasi susigražinti pasitikèjimą tarptautinèse finansu rinkose $(<\ldots>$ we are succeeding very well in gaining back the trust of international financial markets.).

The main function of the majority of such examples is to focus on positive achievements and to deliver the appraisal of the Government's work which inevitably includes the speaker, as the leader of the Government, into the scope of reference. The positive effect this usage of Collective self-reference we could bring about is what Chilton calls the act of bonding among members of one political group (2004, p. 99) by underscoring its inner "sameness" and "togetherness" (2004, p. 100). The interpretation of such usage can range from showing service and concern to the people, which could be regarded as having the value of protection, to indirect boasting and self-praising. For example, the optimism about positive results permeating through examples (25) and (26) may severely contrast with the real economic situation of the majority of Lithuanian households at that time. This contrast may be so sharp as to even result in people taking the Prime Minister's words as ironic with reference to Sperber and Wilson's (1995) conceptualisation of irony as a contrast.

Some interesting examples can be found in the category $I+$ the hearer, to be considered below:

(27) Jei pažvelgtume i kai kuriuos skaičius <...> (If we looked at some numbers $<\ldots>$ );

(28) Pažiūrèkime kaip Europa reaguoja i naciu padarytus nusikaltimus $<\ldots>$ (Let us have a look at how Europe reacts to nazi crimes $<\ldots>$ );

(29) Galime palygint mūsu žmoniu gebejjimą suprasti kilusius iššūkius su kitomis šalimis (We may compare the ability of our people to understand challenges with the people from other countries.). 
In Brown and Levinson's (1987) terms, examples (27-29) could be interpreted as an expression of positive politeness, namely as attendance to the hearer's face and his/her need to be understood and appreciated. In a broader sense, these examples are also an expression of cooperativeness and collaboration, which are, on the one hand, stereotypically regarded as a feature of feminine discourse, but, on the other hand, can be also seen as a typical marker of political and diplomatic discourse and a value appealing to the public.

The second largest category of Collective self-reference we in the former Prime Minister's discourse includes the reference $I+$ Lithuanians/Lithuania, as for instance:

(30) Mes labai orientuoti i eksporta, kuris sudaro apie 60 procentu BVP (We are very much oriented towards export.);

(31) Mūsu istorija ne iš lengvuju - penkiasdešimt metu trukusi okupacija, galybè žmoniu deportuota i Sibira, daug ten kalejjo kaip politiniai kaliniai. Tačiau mes labai greitai atsitieseme (Our history was not easy - fifty years of occupation, numbers of people deported to Siberia, many of them imprisoned for political reasons. However, we recovered very quickly.).

These examples reveal a positive effect on the electorate through the focus on one of the attractive values, namely the value of community. They could be seen as Kubilius' most successful usage where he manages to show himself as part of various social groups in Lithuania. In (30) as the head of the Government who implements the policy on export he includes himself among business people who are affected by this policy. In (31) he shows himself as part of the community who consists of several generations affected by the soviet occupation.

\section{Conclusions}

The present study was an attempt to analyse how the universal values such as responsibility, fairness, honesty, active agency and others are delivered through the choices of self-reference forms such as pronouns and morphological equivalents by two Lithuanian political leaders President Dalia Grybauskaitè and 
former Prime Minister Andrius Kubilius. The aim was to exam how this usage relates to gender and political success. Having the conceptualisation of successful political discourse as communication of values, it was hypothesised that because President Grybauskaite enjoys a stronger support by the public, her discourse, more particularly the use of self-reference forms, is more reflective of universal values than the discourse of the former Prime Minister Kubilius.

Individual self-reference $I$ was found to be used slightly more often by President Grybauskaitè while Collective self-reference we is twice as frequent in the usage of the former Prime Minister Kubilius. Grybauskautè's discourse is thus more reflective of active agency and willingness to show her personal responsibility than the discourse of the former Prime Minister. Kubilius' discourse, on the other hand, shows a considerable move away from active agency to collective and shared responsibility. The usage of Individual self-reference $I$ in Grybauskaitè's discourse tends to mirror a number of universal values such as honesty, openness, fairness, strength and cooperation which are regarded by George Lakoff as appealing to the electorate; conversely, the usage of Individual self-reference $I$ in Kubilius discourse is not reflective of these values.

Although quantitatively the difference in the usage of Collective selfreference we by the two political leaders is much more considerable, with regard to the functional properties of this usage Grybauskaite and Kubilius do not seem to differ as much as in the case of Individual self-reference $I$. Moreover, the move toward cooperativeness in discursive practices, which is a feature traditionally ascribed to feminine usage, can be seen as a property of both politicians' discourse. On the contrary, confrontational discourse, which is generally associated with masculinity, is found much more expressed in Grybauskaitè's usage. Whether it is the use of Individual self-reference $I$ or Collective selfreference we, the President takes every opportunity to juxtapose her stance, which she aims to be viewed as positive in the eyes of the electorate, with that of her opponents, whose activities she shows as harmful to the society.

Given a rather narrow scope of the present study, it does not allow for far-reaching generalisations; however, its findings can still be put in a broader context of current societal developments. Among such developments accelerating globalisation along with breaking of various boundaries could be seen as most significant. Removing the boundaries of traditional gender roles is so advanced, at 
least in the Western societies, that the widely cited features of feminine and masculine linguistic styles could be regarded useful only as descriptors of contextbased language use rather than ascribed to a particular gender, as evidenced by the cooperation-bound discourse of former Prime Minister Kubilius and the straightforwardness of President Grybauskaitè in the present study. Societies thus, as well as the people who comprise them, should be increasingly studied not only as multicultural and multilingual, but also as multi-discursive with different discourses making an impact on how they develop.

\section{References}

Bavelas, J. B., Black, A., Chovil N., \& Mullett, J. (1990). Equivocal Communication. Newbury Park, CA: Sage.

Brown, P. \& Levinson, S. C. (1987). Politeness: Some Universals in Language Usage. Cambridge: Cambridge UP.

Bull, P. (1998). Equivocation theory and news interviews. Journal of Language and Social Psychology. Vol. 17(1), 36-51.

Bull, P. (2000). Equivocation and the rhetoric of modernization: an analysis of televised interviews with Tony Blair in the 1997 British General Election. Journal of Language and Social Psychology. Vol. 19(2), 222-247.

Cameron, D. (1998a). (Ed.). The Feminist Critique of Language: A Reader. $2^{\text {nd }}$ ed. London: Routledge.

Cameron, D. (1998b). 'Is there any ketchup, Vera?': gender, power and pragmatics. Discourse \& Society. Vol. 9(4), 437-455.

Cameron, D. (2003). Gender and Language Ideologies. In J. Holmes and M. Meyerhoff (Eds.), The Handbook of Language and Gender, pp. 447467. Malden: Blackwell.

Holmes, J. (2005). Power and Discourse at Work: Is Gender Relevant? In M. M. Lazar (Ed.) Feminist Critical Discourse Analysis: Gender, Power and Ideology in Discourse, pp. 31-60. Houndmills: Palgrave Macmillan.

Holmes, J. \& Stubbe, M. (2003). "Feminine" Workplaces: Stereotypes and Reality. In J. Holmes and M. Meyerhoff (Eds.), The Handbook of Language and Gender, pp. 573-599. Malden: Blackwell. 
Lakoff, G. (1987). Women, Fire and Dangerous Things: What Categories Reveal about the Mind. Chicago: the University of Chicago P.

Lakoff, G. (1992). Metaphors and war: The metaphor system used to justify war in the gulf. In M. Pütz (Ed.), Thirty Years of Linguistic Evolution, pp. 463481. Philadelphia: John Benjamins.

Lakoff, G. (1996). Moral Politics: What Conservatives Know That Liberals Don't. Chicago: University of Chicago P.

Lakoff, G. (2003). Metaphor and War, Again. Retrieved from: http://www.alternet.org/story.html?StoryID $=15414$.

Lakoff, G. (2004). Don't Think of an Elephant: Know Your values and Frame the Debate. Vermont: Chelsea Green.

Lakoff, R. (1975). Language and Woman's Place. New York: Harper \& Row.

Lakoff, R. (2000). The Language War. Berkeley: the University of California.

Lakoff, R. (2003). Language, Gender, and Politics: Putting "Women" and "Power" in the Same Sentence. In J. Holmes and M. Meyerhoff (Eds.), The Handbook of Language and Gender, pp. 160-178. Malden: Blackwell.

Martín-Rojo, L. (1997). The politics of gender: agency and self-reference in women's discourse. In J. Blommaert and C. Bulcaen (Eds.), Political Linguistics, pp. 231-254. Amsterdam: John Benjamins.

Martín-Rojo, L. \& Gómez, E. C. (2005). The Gender of Power: The Female Style in Labour Organizations. In M. M. Lazar (Ed.), Feminist Critical Discourse Analysis: Gender, Power and Ideology in Discourse, pp. 61-89. Houndmills: Palgrave Macmillan.

Tannen, D. (1990). You Just Don't Understand: Women and Men in Conversation. New York: William Morrow and Company.

Tannen, D. (1994). Talking from 9 to 5. Women and Men at Work: Language, Sex and Power. Lancaster: Virago.

Thimm, C., Koch. S. C., \& Schey, S. (2003). Communicating Gendered Professional Identity: Competence, Cooperation, and Conflict in the Workplace. In J. Holmes and M. Meyerhoff (Eds.), The Handbook of Language and Gender, pp. 528-549. Malden: Blackwell.

Walsh, C. (2001). Gender and Discourse: Language and Power in Politics, the Church and Organisations. Harlow: Pearson Education. 
Wodak, R. (2003). Multiple Identities: The Roles of Female Parliamentarians in the EU Parliament. In J. Holmes and M. Meyerhoff (Eds.), The Handbook of Language and Gender, pp. 671-698. Malden: Blackwell.

Wodak, R. (2005). Gender Mainstreaming and the European Union: Interdisciplinary, Gender Studies and CDA. In M. M. Lazar (Ed.), Feminist Critical Discourse Analysis: Gender, Power and Ideology in Discourse, pp. 90-113. Houndmills: Palgrave Macmillan.

\author{
Vilma Bijeikienè \\ Vytauto Didžiojo universitetas, Lietuva \\ vilma.bijeikiene@vdu.It \\ Nemira Mačianskienè \\ Vytauto Didžiojo universitetas, Lietuva \\ nemira.macianskiene@vdu.lt
}

\title{
POLITINIS LIETUVOS DISKURSAS: ATSTOVAVIMO IR ATSAKOMYBÉS RAIŠKA
}

Santrauka. Keičiantis Iyties atstovavimo politikoje, o ypač politinèje lyderystèje, situacijai, Lietuvai turètu būti skiriamas ypatingas demesys, analizuojant moteru politiniu lyderiu sékmės pavyzdžius. Viena vertus, bendra moteru parlamentariu dalis Lietuvos Seime tikrai nèra ispūdinga: 26 moterys (18\%) ir 115 vyru (82 \%) dirbo 2008-2012 metu kadencijoje bei 34 moterys (24\%) ir 107 vyrai buvo išrinkti 2012 metu rinkimuose. Tačiau, žvelgiant iš kitos pusès, 2008-2012 metu kadencijoje moterys užèmè aukščiausius politinius postus Lietuvoje - Lietuvos Prezidentè Dalia Grybauskaitè, Seimo pirmininkè Irena Degutienè, Finansu ministre Ingrida Šimonyte ir Krašto apsaugos ministrè Rasa Juknevičienè. Tokia situacija galima būtu traktuoti kaip lūžio tašką, atsižvelgiant i plačiai cituojamas stereotipines prielaidas, kad profesijos susietos su politika, ekonomika ar kariniais klausimais yra tipiškos vyriškos profesijos (R. Lakoff, 2000, 2003; Walsh, 2001), arba, anot statistiniu duomenu pateiktu Wodak (2003), kad moterys retai užima aukščiausias vadovaujančias pareigas. Beveik ipusèjusi antraja kadencija prezidentè Grybauskaitè, sulaukia gana ženklaus žmoniu palaikymo pagal populiarumo reitingus. Tai rodo ne tik dramatišką poslinki nuo tradicinio lyčiu paskirstymo, kai moterys buvo "nutildytos" (Cameron, 1998; R. Lakoff, 1975), bet taip pat gana ryšku žingsni pereinant nuo moteriško pasipriešinimo ir išlikimo diskurso, apie kuri kalba Martin-Rojo (1997) prie sèkmès diskurso. Kaip teigia G. Lakoff (2004), tam, kad politinè kalba atneštu sèkmę, ji turi būti grindžiamas vertybèmis. Atsižvelgiant i šiuos pastebèjimus, straipsnyje keliamas tikslas išnagrinèti, kaip pagrindiniai Lietuvos politiniai lyderiai - Prezidentè Dalia Grybauskaitè ir buvęs Ministras Pirmininkas Andrius Kubilius išreiškia tokias vertybès kaip atsakomybė, sažiningumas, aktyvus atstovavimas ir t. t. pasirinkdami ivardžius (plg. Wilson, 1990) bei ekvivalentiškas morfologines formas. Analizuojami duomenys paimti iš politiniu interviu tekstu, pateikiamu žiniasklaidoje. Tyrimas daugiausia remiasi kokybine diskurso analize ir kiekybinio tyrimo elementais.

Pagrindinès sąvokos: atstovavimas, jvardinès formos, lyderystè, lytis, nuoroda i save, politinis diskursas. 